\title{
A Estrutura Acusatória da Investigação \\ CRIMINAL: ANÁlise A PARTIR DA LeI N. 13.964/2019
}

\author{
The Adversarial Structure of the Criminal \\ INVESTIGATION: ANALISYS AFTER THE LAW N. \\ $13.964 / 2019$
}

\section{Análisis de la Estructura Acusatoria de la Investigación Penal: ANÁlisis a Partir de la LeY N. 13.964/2019}

Thiago Pierobom de Ávila*

\begin{abstract}
1 Introdução. 2 A projeção do sistema acusatório à fase investigativa. $3 \mathrm{O}$ afastamento do juiz das garantias da iniciativa investigativa. $4 \mathrm{~A}$ regra de impedimento entre o juiz das garantias e o juiz da instrução e julgamento. $5 \mathrm{O}$ afastamento do juiz do controle do arquivamento do inquérito policial. $6 \mathrm{~A}$ função judicial de controle do acordo de não persecução penal. 7 Análise crítica da convergência da reforma a um modelo acusatório projetado à investigação criminal. 8 Considerações finais. Referências.
\end{abstract}

\section{RESUMO}

Objetivo: $O$ presente artigo objetiva reconhecer a estrutura acusatória na fase da investigação criminal implementada pela Lei $\mathrm{n}^{\circ}$ 13.964/2019, analisando sua constitucionalidade e esclarecendo as possíveis antinomias hermenêuticas.

Metodologia: Utiliza-se do método jurídico hermenêutico dedutivo e de análise, bem como da técnica de interpretação sistemática à luz do referencial teórico do sistema acusatório.

"Doutor em Ciências Jurídico-Criminais pela Universidade de Lisboa (Portugal), com Pós-Doutorado em Criminologia pela Universidade Monash (Austrália). Professor Associado do PPGD do Centro Universitário de Brasília (UniCEUB) e Investigador Integrado do Instituto de Direito Penal e Ciências Criminais da Universidade de Lisboa. Promotor de Justiça do MPDFT. E-mail: <thiago.pierobom@hotmail.com>.https://orcid.org/0000-0001-8163-5806 
Resultados: Reconhecem-se três pontos relevantes na reforma: (i) o juiz das garantias; (ii) o afastamento do controle judicial do arquivamento da investigação criminal; e (iii) o afastamento do juiz da iniciativa de celebração do acordo de não persecução penal. Refutam-se os argumentos de inconstitucionalidade utilizados por decisão liminar do STF na ADIN 6299.

Contribuições: $\mathrm{O}$ afastamento do juiz das iniciativas de investigação e de decisão ex officio sobre a restrição de direitos fundamentais eleva sua imparcialidade objetiva. $\mathrm{O}$ Ministério Público passa a ser o gestor da investigação criminal, controlando internamente o arquivamento do inquérito e tendo a iniciativa extrajudicial do acordo de não persecução penal. $O$ investigado e a vítima também têm novas garantias regulamentadas. Indicam-se áreas de necessário ajuste hermenêutico.

Palavras-chave: Sistema Acusatório. Investigação Criminal. Juiz das Garantias. Ministério Público. Imparcialidade.

\section{ABSTRACT}

Objective: This paper recognizes the adversarial structure of the criminal investigation on the Law 13.964/2019, supports its constitutionality and clarify possible hermeneutical antinomies.

Methodology: It uses the deductive and analytical legal hermeneutic methodology and the technic of systematic interpretation, using the theory of the adversarial system.

Results: It recognizes three relevant aspects on the Law reform: (i) the judge of guarantees; (ii) the interdiction of judicial control of the decision of closing the investigation; and (iii) the interdiction of judicial initiative for the new plea bargaining. It refutes the arguments of unconstitutionality used in a preliminary decision of the Brazilian Supreme Court.

Contributions: The interdiction of judicial ex officio initiative during the criminal investigation raises his objective impartiality. The prosecution office is the manager of the criminal investigation, closing internally the investigation and celebrating outside court the plea bargaining. Both the inquired person and the victim have new rights. The paper indicates topics of necessary hermeneutical adjustment.

Keywords: Adversarial System. Criminal Investigation. Judge of Guarantees. Prosecution Office. Impartiality.

\section{RESUMEN}


Objetivo: Este artículo tiene como objetivo reconocer la estructura acusatoria en la fase de la investigación penal implementada por la Ley n. 13.964/2019, analizando su constitucionalidad y aclarando posibles antinomias hermenéuticas.

Metodología: Utiliza el método de análisis legal deductivo y hermenéutico y la técnica de interpretación sistemática a la luz del marco teórico del sistema acusatorio.

Resultados: Se reconocen tres puntos relevantes en la reforma: (i) el juez de garantías; (ii) la eliminación del control judicial del sobreseimiento; y (iii) la prohibición del juez tener iniciativa en el acuerdo penal. Los argumentos de inconstitucionalidad utilizados por la decisión preliminar del STF en la ADIN 6299 son refutados.

Contribuciones: La retirada del juez de las iniciativas de investigación y de decisión de oficio sobre la restricción de derechos fundamentales eleva su imparcialidad objetiva. El Fiscal se convierte en el administrador de la investigación penal, controlando internamente el sobreseimiento y celebrando de forma extrajudicial el acuerdo penal. El investigado y la víctima también tienen nuevas garantías reguladas. Se indican las áreas de ajuste hermenéutico necesario.

Palabras clave: Sistema Acusatorio. Investigación Criminal. Juez de Garantía. Ministerio Fiscal. Imparcialidad.

\section{INTRODUÇÃO}

A Lei no 13.964/2019 introduziu diversas reformas no Código Penal, Código de Processo Penal, Lei de Execuções Penais e legislação especial. No âmbito processual penal, a reforma do denominado "pacote anticrime" tem como ponto nevrálgico a incorporação da estrutura acusatória à fase da investigação criminal. Ela segue a linha de reformas temáticas anteriores, como a do procedimento do júri e do procedimento em geral (Leis no 11.689/2008 e 11.719/2008), do sistema probatório (Lei no 11.690/2008) e do sistema cautelar (Lei no 12.403/2011).

A lei, publicada em 24/12/2019, entrou em vigor em 23/01/2020. Inicialmente, o Presidente do STF, Min. Dias Toffoli, concedeu decisão monocrática liminar na ADIN 6298 (BRASIL, 2020a) e adiou a vigência dos dispositivos relacionados ao juiz das garantias em até 180 dias após sua decisão ou prazo menor conforme a capacidade de organização dos tribunais locais. Posteriormente, o Vice-Presidente, Min. Luiz Fux, reviu essa decisão (BRASIL, 2020b) para suspender sine die a vigência dos dispositivos relacionados ao juiz das garantias bem como do arquivamento interno do Inquérito Policial - IP pelo Ministério Público, ad referendum do Plenário do STF. 
Essa última decisão considerou que a instituição de uma regra de impedimento entre as fases de investigação e julgamento teria natureza híbrida, ao mesmo tempo processual e procedimental, pelo que seria tema afeto à lei de organização judiciária, de competência legislativa federal. Também seria inconstitucional por não criar cargos de juízes para exercer as novas funções nem dotações orçamentárias aos Tribunais. Em relação ao arquivamento interno do IP no Ministério Público, considerou-se que a reforma geraria grande impacto financeiro na reestruturação dos serviços ministeriais, violando a cláusula constitucional de prévia dotação orçamentária. Em ambos os casos, entendeu-se que as alterações deixaram lacunas interpretativas com consequências operacionais significativas, e postergou-se para o mérito a análise aprofundada dos novos institutos.

Com efeito, os novos institutos processuais terão um impacto massivo no dia a dia no sistema de justiça criminal, exigindo um substancial rearranjo nas relações entre Ministério Público e o novo juiz das garantias, com diversas repercussões não regulamentadas pela reforma. Todavia, a tese da inconstitucionalidade total é frágil, sendo previsível sua revisão pelo Plenário do Excelso Pretório, com uma interpretação sistemática que permita suprir as lacunas deixadas pela nova lei.

$\mathrm{O}$ presente artigo objetiva analisar a constitucionalidade e as consequências teóricas e práticas da nova estrutura acusatória à fase investigativa, clareando os espaços de dúvida advindos da reforma. Serão discutidos três pontos específicos: (i) a criação do juiz das garantias; (ii) o afastamento do juiz do controle do arquivamento da investigação criminal; e (iii) o afastamento do juiz da iniciativa de celebração do Acordo de Não Persecução Penal - ANPP. Em relação ao juiz das garantias, discute-se sua constitucionalidade (e necessidade) à luz do sistema acusatório, analisando-se a regra de impedimento para o julgamento e os limites de suas atribuições.

Será utilizado o método jurídico-hermenêutico dedutivo e de análise (CEPEDA, 2006, p. 47), com especial recurso à técnica da interpretação sistemática e à luz das diretrizes constitucionais, considerando o referencial teórico do sistema acusatório aplicado à fase investigativa (MESQUITA, 2003; RIBEIRO, 2003; PRADO, 2005; SANTIN, 2007; MATA-MOUROS, 2011; SILVA, 2010; ÁVILA, 2016a). Espera-se contribuir no debate quanto à constitucionalidade da reforma e à solução dos possíveis conflitos interpretativos, com a sedimentação hermenêutica de um novo paradigma de investigação criminal mais alinhado com a imparcialidade judicial e com o complexo equilíbrio dos direitos fundamentais de todos os envolvidos na persecução penal: investigado, vítima e sociedade. 


\section{A PROJEÇÃO DO SISTEMA ACUSATÓRIO À FASE INVESTIGATIVA}

Historicamente, os sistemas processuais europeus continentais evoluíram a partir de um modelo inquisitivo, com a influência do direito canônico, em que o juiz acumulava as funções de investigar, acusar e julgar (ANDRADE, 2008). Por outro lado, modelos anglo-saxões evoluíram a partir das características de ação penal popular e julgamento pelo júri, com perfil adversarial de maior disponibilidade pelas partes e menor iniciativa pelo magistrado (PRADO, 2005). A característica marcante do sistema acusatório é o distanciamento do juiz da iniciativa acusatória e da gestão da prova. Segundo definição clássica de Marques (2019, p. 23), um sistema acusatório possui as seguintes características: a) separação entre os órgãos de acusação, defesa e julgamento, com um processo de partes; b) liberdade de defesa e igualdade entre as partes; c) contraditório; d) liberdade probatória e livre convencimento judicial; e) inércia judicial no impulso processual (ne procedat judex ex officio). Alguns acrescentam também a publicidade, oralidade, a coisa julgada e possibilidade de duplo grau de jurisdição como características (LOPES JUNIOR, 2003; PRADO, 2005; CUNHA, 2020, p. 69).

Essa dicotomia histórica tem cedido espaço a uma nova construção teórica sobre o sistema acusatório enquanto sinônimo de um sistema de garantias de direitos para todos os intervenientes da persecução penal, que tem como pressuposto a delimitação das funções, dos direitos e dos deveres desses sujeitos no processo (v. FERRAJOLI, 2002). Assim, os sistemas concretos se aproximariam mais ou menos de modelos teóricos de tendência inquisitiva/autoritária ou garantista/acusatória (HIRECHE, 2020). Segundo Schneider e Callegari (2018, p. 195), há uma "relação histórica entre o processo de aquisição de direitos e o sistema acusatório no Brasil."

A Constituição Federal de 1988 constitui uma virada axiológica no Processo Penal brasileiro, afastando-se de um modelo autoritário e consolidando um paradigma que procura equilibrar a necessária efetividade da tutela criminal em prol da sociedade e da vítima com um sistema de garantia de direitos ao sujeito passivo da intervenção estatal. Segundo a Constituição Federal, um dos pilares desse sistema é o princípio acusatório, insculpido em seu art. 129, inciso I, que representa uma separação de funções entre as atividades próprias de promoção da persecução penal e a intervenção judicial. Um sistema acusatório vai além desse princípio e incorpora a presunção de inocência e o ônus da prova pela acusação, assim como a necessidade de direitos de defesa e de garantias de respeito às expectativas da vítima, igualmente previstas no texto constitucional (CF/1988, art. 5\%).

A projeção do modelo acusatório à fase investigativa, com a extinção do juiz instrutor, expandiu-se de diversos países do sistema europeu continental (como Alemanha, Portugal e Itália) para o CPP Modelo Ibero-americano e daí para diversos 
países da América Latina, ainda que com matizes individuais (v. GRINOVER, 2000; LOPES JUNIOR, 2003; ÁVILA, 2016a; MAYA, 2018; FERNÁNDEZ; MORALES, 2018; ANDRADE, 2020; CARVALHO; MILANEZ, 2020). Segmento expressivo da doutrina nacional argumenta que a estrutura acusatória se projeta à fase investigativa (v. LOPES JUNIOR, 2003; MESQUITA, 2003; PRADO, 2005; SANTIN, 2007; ÁVILA, 2016a). Com efeito, a dominialidade da investigação pelo Ministério Público é a única opção compatível com a titularidade privativa da ação penal e com um modelo acusatório (v. MESQUITA, 2003, p. 154-163).

Portanto, em uma investigação criminal moldada pelo sistema acusatório, cabe ao Ministério Público acompanhar e direcionar a atividade de coleta de informações preliminares para a formação de sua decisão de acusação, não acusação ou de proposta de solução consensual do caso. Caberá ao juiz intervir nas hipóteses em que for acionado para controlar as restrições de direitos fundamentais do sujeito passivo, seja autorizando medidas cautelares e diligências investigativas qualificadas por essa restrição de direitos, seja apreciando eventuais impugnações à legalidade da investigação criminal formuladas pela defesa. O investigado deixa de ser visto como mero objeto da investigação e passa a ser reconhecido como sujeito de direitos, especialmente os direitos de respeito à sua integridade física e de não ser obrigado a produzir prova contra si (conforme amplo rol dos incisos do art. 5 da CF/1988), com a possibilidade de ter vista dos autos e impugnar ilegalidades, até o exercício de um contraditório mitigado nessa fase, consistente na liberdade de prestar informações para esclarecer eventual curso equivocado das investigações ou de contraditar, ainda que, a posteriori, eventuais restrições de direitos. Igualmente, conforme argumenta Fernández e Morales (2018, p. 90), "a paridade do sistema acusatório também deve se projetar em benefício da vítima do delito." Assim, a vítima passa a ser reconhecida como sujeito de direitos, desde direitos de informação, proteção, reparação e tratamento não revitimizante pelo sistema de justiça, até a possibilidade de impugnar eventuais arquivamentos das investigações que considerar indevidos ou promover a ação penal privada subsidiária da pública em caso de inércia do Ministério Público (CF/1988, art. 5, LIX). Finalmente, a polícia, apesar de não ser sujeito processual, intervém como órgão de colaboração com a atividade processual do Ministério Público, que é o titular da persecução penal em juízo e responsável pelo controle externo da atividade policial (CF/1988, art. 129, incisos I e VII).

Esse conjunto de funções também estabelece restrições de atuação: não cabe ao magistrado ter poder de inciativa de investigação ou de promoção da acusação, não pode o Ministério Público ter poderes de restrição de direitos fundamentais do investigado, e não pode a autoridade policial conduzir uma investigação criminal fora do quadro de controle pelo titular da persecução penal. Nesse último ponto, afirma Mesquita (2003,

6 - R. Opin. Jur., Fortaleza, ano 19, n. 32, p.1-31, set./dez. 2021 
p. 104) que, "à luz de uma leitura funcional, a responsabilidade de decidir a acusação e sustentá-la efetivamente em juízo constitui um freio aos excessos do investigador”. A demanda de realização do sistema penal deve estar equilibrada com as garantias de proteção do investigado, já que um sistema de garantismo integral deve ponderar todos os direitos fundamentais em jogo na persecução penal: do investigado, da vítima e da sociedade ${ }^{1}$.

Essa figura do juiz das garantias possui paralelo na maioria dos países europeus, que separam os juízes nessas duas fases e atribuem a condução da fase investigativa ao Ministério Público (v. ÁVILA, 2016a, cap. 1). Há precedentes do TEDH (1982) sobre a necessidade de impedimento entre os magistrados que atuam nas duas fases, em funções de promotor ou juiz instrutor (v. LOPES JUNIOR; RITTER, 2016; MAYA; LORENZONI, 2020). No mesmo sentido, o art. 18 do Estatuto da Corte Europeia de Justiça estabelece expressamente o impedimento do magistrado que exerceu funções na investigação ou no julgamento do caso nas fases processuais anteriores. Nos países que ainda trabalham com a figura do juiz de instrução (um juiz responsável por diretamente conduzir a investigação criminal), como Espanha e França, houve necessidade de se criar outro juiz para exercer as funções de controle da restrição de direitos fundamentais. É o caso da França, que trabalha com a figura do juiz de instrução para os crimes com penas superiores a 10 anos ou com penas menores que exijam a prisão preventiva, mas criou o juiz das liberdades para as decisões de restrições de direitos solicitadas pelo juiz de instrução (ÁVILA, 2016a, p. 77-93).

O juiz das garantais consta da recomendação do Código de Processo Penal modelo para a Íbero-América, que prevê a "atribuição da investigação prévia ao Ministério Público, com a intervenção do juiz para as medidas cautelares" (GRINOVER, 2000, p. 950). Nessa linha, vários países Latino-Americanos realizaram reformas tendentes à implementação do juiz das garantias (v. MAYA, 2018). Por exemplo, no Chile, o Código de Processo Penal (Ley 19.696/2000) prevê em seu art. 3o que "O Ministério Público dirigirá de forma exclusiva a investigação dos fatos constitutivos de delito [...]” (CHILE, 2000, online), com a previsão, no art. 9o, de que o Ministério Público poderá solicitar a intervenção do “juez de garantías” para as diligências restritivas de direitos fundamentais na fase investigativa, um juiz distinto do "tribunal de juicio oral” para o julgamento. Na mesma linha, o novo Código de Processo Penal Federal da Argentina (Ley 27.063/2014, compilada em suas alterações pelo Decreto 118/2019), estabelece em seu art. 9 a regra de separação de funções, prevendo que "Os representantes do Ministério Público não podem realizar atos propriamente jurisdicionais e os juízes não podem realizar atos de investigação ou que impliquem em

\footnotetext{
${ }^{1}$ Por exemplo, a proposta de Ferrajoli (2002, p. 446) de absoluta inadmissibilidade da prisão provisória antes do trânsito em julgado é incompatível com o quadro constitucional brasileiro.
} 
impulso da persecução penal", e estabelece no art. 52 uma distinção entre "los jueces con funciones de juicio" e "los jueces con funciones de garantías", este último limitado à fase investigativa e de homologação de acordos (ARGENTINA, 2014, online).

Há mais de uma década, o instituto do juiz das garantias é discutido no Congresso Nacional, tendo o Senado aprovado projeto de novo CPP com a inclusão do juiz das garantias, mas a proposta não avançou na Câmara dos Deputados (PLC 8045/2010), diante das gestões parlamentares contrárias pela magistratura, usualmente ao argumento de falta de estrutura. A proposta do juiz das garantias não constava da proposta original do Ministério da Justiça, sendo inserida na tramitação legislativa da atual Lei $\mathrm{n}^{\circ}$ 13.964/2019, com um debate político tímido (v. SUXBERGER, 2020) sobre a dubiedade do regime processual então em vigor, que permitia em suas brechas uma colaboração ativa do juiz no sucesso das investigações, com risco de comprometimento de sua imparcialidade.

É notório que as reformas processuais de garantia de direitos apenas são realizadas quando o sistema penal passa a tocar em crimes praticados por integrantes das elites, cujo exemplo mais eloquente é a Lei Fleury (Lei n. 5.941/1973), que aboliu a prisão preventiva obrigatória após a pronúncia ou após a condenação em primeira instância depois da prisão de Sérgio Fleury, com fortes ligações políticas com o regime militar. Em tempos recentes, os crimes de colarinho branco passaram a receber resposta mais acentuada, inclusive em relação a segmento expressivo do campo político. Todavia, a análise da reforma deve ser feita de forma técnica, avaliando se a nova regra procura aperfeiçoar uma possível falha do sistema anterior sem sacrificar de forma desarrazoada a sua efetividade. Garantias e efetividade devem estar em constante equilíbrio (ÁVILA, 2016a).

\section{O AFASTAMENTO DO JUIZ DAS GARANTIAS DA INICIATIVA INVESTIGATIVA}

Havia inegavelmente ranços inquisitivos em nossa legislação quanto à função do juiz na fase investigativa. Segundo normas ainda hoje não revogadas expressamente (mas tacitamente revogadas, como se verá adiante), era possível ao juiz requisitar a instauração do inquérito, já apontando o suspeito e a infração penal (CPP, art. 5º, inciso II e § 2०), decretar de ofício a produção antecipada de provas na fase das investigações (CPP, art. 156, inciso I), ser visto como o destinatário do inquérito e apreciar os pedidos de prorrogação do inquérito de investigado solto (CPP, art. 10, $\S \S 1^{\circ}$ e 3o), requisitar diligências investigatórias (CPP, art. 13, inciso II), determinar de ofício busca e apreensão domiciliar (CPP, art. 242), indiretamente promover a ação penal ao requerer ao Procurador-Geral de Justiça que ajuíze denúncia, quando discordar da promoção de

8 - R. Opin. Jur., Fortaleza, ano 19, n. 32, p.1-31, set./dez. 2021 
arquivamento feita pelo Promotor de Justiça (CPP, art. 28, antiga redação). Depois disso tudo, ainda realizar o julgamento da ação penal! A doutrina já criticava esses resquícios inquisitivos do juiz (v. LOPES JUNIOR, 2003; PRADO, 2005), mas parte do sistema de justiça ainda se apegava a esses poderes de iniciativa na fase investigativa, em nome da suposta eficiência do futuro julgamento que seria de responsabilidade do juiz e de um poder geral de cautela na fase investigativa.

Segmento da doutrina já apontava a não recepção dessas normas inquisitivas pelo paradigma constitucional, indicando que as novas atribuições dadas ao juiz das garantias já deveriam ser reconhecidas mesmo antes da reforma. Afirma Ávila (2016a, p. 157): "O afastamento do juiz da atividade de investigação é uma das principais características do sistema acusatório; [...] O papel do juiz na fase das investigações é de árbitro imparcial da legalidade da restrição de direitos fundamentais, um verdadeiro juiz de garantias." $\mathrm{Na}$ mesma linha, o STF possuía precedentes analisando o papel do magistrado nas ações penais originárias de tribunal, tendo afirmado que o juiz não pode atuar como um investigador, mas "apenas atua como um administrador, um supervisor, um coordenador, no que concerne à montagem do conjunto probatório e às providências acautelatórias, agindo sempre por provocação, jamais de ofício", e que, "entre nós, a intervenção do judiciário ao longo do inquérito objetiva coibir eventuais excessos ou desvios por parte dos agentes policiais, bem como impedir ações ou omissões ilegais ou abusivas por parte de qualquer outra autoridade envolvida na investigação" (BRASIL, 2008, online). Já há algum tempo, a conveniência política do juiz das garantais tem sido objeto de análise pela doutrina nacional, com posições favoráveis (BADARÓ, 2011; CHOUKR, 2011; GIACOMOLLI, 2011; LOPES JUNIOR; RITTER, 2016; MAYA, 2018) e contrárias (ANDRADE, 2020; SUXBERGER, 2020).

A reforma da Lei n. 13.964/2019 “escolhe um lado", trazendo diretrizes principiológicas que caminham para o rompimento dos ranços inquisitivos (v. HIRECHE, 2020; CUNHA, 2020; MAYA; LORENZONI, 2020) ${ }^{2}$, sendo "representativa de uma tendência democrática" (CARVALHO; MILANEZ, 2020, p. 108). O novo art. 30-A do CPP estabelece que o processo penal possui estrutura acusatória e que o juiz não poderá ter iniciativa na fase investigatória e não poderá substituir a atividade probatória da acusação. Esse dispositivo é complementado pelo seguinte, o art. 3-B, que traz um rol das atividades do juiz das garantias, ou seja, o juiz que atua na fase investigativa. Essas normas de natureza principiológica dão concretização ao princípio acusatório previsto na CF/1988, art. 129, inciso I, e devem moldar toda a estrutura do processo penal. Ainda que algumas das referidas normas

\footnotetext{
${ }^{2}$ Hireche (2020) argumenta que a persistência de vigência do art. 156 do CPP, permitindo ao magistrado a iniciativa probatória no curso do julgamento, levaria à persistência de nosso sistema de natureza inquisitiva, agora com características assessórias acusatórias.
} 
inquisitivas não tenham sido expressamente revogadas, a nova interpretação sistemática (e, agora, em maior conformidade com a Constituição) permite concluir que houve uma revogação tácita dos poderes de iniciativa investigativa ou de promoção da ação penal pelo magistrado.

Com a reforma, o inquérito policial passa a ser um "procedimento para a acusação" (MESQUITA, 2003, p. 125). Agora, o juiz das garantias apenas atuará se for provocado por uma das partes, para uma das hipóteses previstas no seu rol de competências, que são, em síntese, a realização da audiência de custódia, apreciação dos requerimentos de medidas cautelares e diligências investigativas qualificadas pela reserva de jurisdição, análise de eventuais impugnações formuladas pelo investigado quanto à legalidade da investigação, audiência de homologação do ANPP e recebimento da denúncia.

No âmbito das decisões sobre as medidas investigativas restritivas de direitos fundamentais do investigado, estão nas atribuições do juiz das garantias o controle das prisões em flagrante na audiência de custódia (CPP, art. 3o - B, caput, inciso II) e a decretação de prisão preventiva e medidas cautelares (inciso V). $\mathrm{O}$ art. 3-B, inciso XI, traz um rol de diligências qualificadas pela reserva de jurisdição. Esse rol é evidentemente exemplificativo, cf. alínea "e", pois todas as diligências investigativas legalmente qualificadas com a reserva de jurisdição serão da competência deste juiz das garantias. Esta cláusula final exemplificativa não está criando uma exigência genérica de reserva de jurisdição, mas remetendo às já existentes, conforme legislação e jurisprudência.

A introdução do juiz das garantias está associada a outra reforma: a proibição de iniciativa do juiz para a concessão de medidas cautelares criminais, tanto na fase da investigação quanto em juízo (CPP, art. 282, § 20). Ainda se mantém a possibilidade de a autoridade policial representar pela medida cautelar na fase investigativa, que deve ser perspectivada como um órgão de auxílio do titular da persecução penal (ÁVILA, 2016a, p. 187).

A reforma legaliza a audiência de custódia no novo art. 310, caput, do CPP. Anteriormente determinada pelo STF (BRASIL, 2015) e regulamentada pelo CNJ (Resolução no 213/2015), com fundamento em norma da Convenção Interamericana de Direitos Humanos (art. 7.5), a audiência de custódia passará a ser realizada pelo juiz das garantias. Nada impede que os Tribunais criem regime de plantão centralizado para realizar a audiência de custódia, mas o magistrado designado, por regras objetivas, sempre exercerá a função processual de juiz das garantias.

Considerando a nova estrutura acusatória da investigação criminal, derivada da conjugação dos art. 3-A e art. 282, § 2º, do CPP, não poderá o juiz das garantias, na audiência de custódia, decretar de ofício a prisão preventiva, sendo essencial que haja 
requerimento pelo Ministério Público ou representação pela autoridade policial. O mero auto de prisão em flagrante não é uma representação policial pela decretação da prisão preventiva, pois a polícia não possui discricionariedade em não efetuar a prisão. Abre-se a possibilidade de a autoridade policial, ao lavrar o APF, representar (ou não) concomitantemente pela prisão preventiva, mas sempre comunicar a prisão em flagrante ao juiz e apresentar-lhe o preso, sem prejuízo do posicionamento do Ministério Público na audiência de custódia.

A plena incorporação do sistema acusatório à fase preliminar deveria possibilitar a autodefesa para a decisão sobre a decretação da prisão preventiva. Em diversos países, há a garantia de primeiro interrogatório judicial ao investigado preso, a ser realizado na audiência de custódia, enquanto instrumento de prevenção de ilegalidades e de maximização do direito de defesa, já que o interrogatório na fase investigativa não possui finalidade primária de ato de investigação, mas de oportunidade de defesa num ambiente livre de eventuais pressões (v. ÁVILA, 2016b). Atualmente, as audiências de custódia são um ato kafkaniano, pois o juiz deve decidir sobre os requisitos para a decretação da prisão preventiva, mas não se permite que o preso possa falar sobre os fatos que subsidiarão a respectiva tomada de decisão.

$\mathrm{O}$ art. 3-B, inciso IV, do CPP prevê que o juiz das garantias será comunicado da instauração de investigação criminal. Essa comunicação é mero ato administrativo de controle da existência de investigação criminal, sem conteúdo jurisdicional, uma garantia contra investigações secretas, ressalvado o sigilo de atos investigatórios pendentes de realização (CPP, art. 3º-B, inciso XV). Não há necessidade de que o juiz das garantias autorize o início ou a continuidade da investigação, apenas que seja comunicado de sua instauração pela autoridade competente.

A lei não prevê no rol das competências do juiz das garantias autorizar a prorrogação do prazo para a continuidade das investigações de investigado solto, estando esse tema totalmente fora do quadro sistemático das atribuições do magistrado na fase investigativa. $O$ controle da eficiência da investigação, portanto dos prazos das diligências, é atribuição exclusiva do Ministério Público (cf. CF/1988, art. 129, inciso VIII, e LC n. 75/1993, art. 7º inciso II, c/c art. 8, § 5). Apenas na situação de prorrogação de prazo do inquérito quanto a investigado preso é que será necessária a prévia autorização judicial, exatamente pelo fato de importar numa restrição de direitos do investigado, pela continuidade da sua custódia (CPP, art. 3º-B, inciso VIII).

Portanto, entendemos que a reforma revogou tacitamente os $\S \S 1^{\circ}$ e $3^{\circ}$ do art. 10 do CPP, que previam o sistema de tramitação triangular do IP, via Judiciário. Em outras palavras, o juiz das garantais não é o destinatário do material investigativo produzido pela polícia, quem decide sobre o destino da investigação criminal é o Ministério Público, com sua decisão de arquivamento, de acordo ou de promoção da ação penal 
(ÁVILA, 2016a). É perfeitamente possível, em caso de investigado solto, com investigação sem necessidade de diligências restritivas de direitos fundamentais, com posterior arquivamento da investigação pelo Ministério Público, que o juiz das garantias nunca seja acionado ou que seja acionado pela primeira vez com o oferecimento da denúncia.

A reforma nem sequer exige que o inquérito seja autuado e distribuído a um juiz das garantias no início da investigação, da mesma forma que o Procedimento Investigatório Criminal - PIC conduzido diretamente pelo Ministério Público não tramita via Judiciário (Resolução n. 181/2017 - CNMP). Quando há arquivamento do inquérito, o juiz das garantias nem sequer é comunicado (CPP, art. 28, caput), reforçando a ideia de que o inquérito não tramita via Judiciário. Agora, não há mais requerimento judicial de declínio de competência na fase investigativa, tão somente declínio de atribuições perante os órgãos do Ministério Público. Entendemos que é possível à vítima impugnar essa desclassificação, equivalente a um arquivamento parcial, mediante aplicação analógica do novo sistema do art. 28 do CPP.

O juiz das garantais também possui uma função de controle sobre a legalidade da investigação criminal. $\mathrm{O}$ controle exercido pelo juiz das garantias é exclusivo para as situações de eventuais restrições de direitos do investigado, ou seja, pode determinar o trancamento de uma investigação criminal quando não houver justa causa (v.g., por fato evidentemente atípico, já prescrito ou sem condição de procedibilidade), a denegação de acesso dos autos da investigação ao advogado do investigado, o julgamento de habeas corpus ou ainda atividades para zelar pela não divulgação abusiva da imagem do preso (CPP, art. 3-B, incisos IX, XII e XV, e art. 3-F). Por isso, a atribuição de requisitar documentos à autoridade policial sobre o andamento da investigação (art. 3-B, inciso X) deve ser compreendida dentro dos limites dessas atribuições, ou seja, se houver uma impugnação de ilegalidade pela defesa do investigado, poderá o magistrado pedir informações para então julgar (v. ANDRADE, 2020, p. 105). Esse pedido não está relacionado à fiscalização quanto ao sucesso da investigação ou seu direcionamento, funções exclusivas do Ministério Público, enquanto titular da persecução penal e órgão de controle externo da atividade policial (CF/1988, art. 129, incisos I e VII).

Finalmente, o trancamento do inquérito ocorrerá quando "não houver fundamento razoável para sua instauração ou prosseguimento" (art. 3o-B, inciso IX); havendo um indício razoável da materialidade de um delito, o correto será o prosseguimento das investigações, exatamente para poder confirmar ou refutar as eventuais hipóteses explicativas da notitia criminis. Nessa situação, "O sistema acusatório não permite ao juiz adiantar-se ao Ministério Público na formação da opinio delicti, determinando certa tolerância na continuidade das investigações para se reunir a prova 
do fato que, em tese, o Ministério Público entende ter ocorrido.” (ÁVILA, 2016a, p. 358).

A competência do juiz das garantias cessa com o recebimento da denúncia ou queixa (CPP, art. 3-C, caput). A partir desse momento, a competência para manter ou rever as medidas cautelares em curso passará ao juiz da instrução e do julgamento. Os autos encaminhados ao juiz da instrução e do julgamento serão os da investigação criminal com a denúncia e seu recebimento, com a regra de que os demais procedimentos de competência do juiz das garantais ficarão arquivados na respectiva secretaria, ressalvados "os documentos relativos às provas irrepetíveis, medidas de obtenção de provas ou de antecipação de provas" (art. 3-C, § 3), que serão apensados aos autos principais. Aparentemente, não serão encaminhadas eventuais impugnações realizadas pela defesa, como habeas corpus ou solicitações de acesso aos autos, bem como as diligências investigativas solicitadas pelo Ministério Público e indeferidas pelo juiz. Todavia, em caso de prisão preventiva, considerando que o juiz da instrução e do julgamento deverá necessariamente rever a necessidade da manutenção custódia no prazo de 10 dias (art. 3-C, $\S 2^{\circ}$ ), parece-nos essencial que os autos do requerimento de prisão também sejam transmitidos ao juiz da instrução e do julgamento, para que este possa ter acesso às informações e às argumentações de ambas as partes sobre a necessidade ou não de manutenção das medidas cautelares.

Essa regra de não encaminhamento dos autos de temas de competência do juiz das garantias ao juiz da instrução não significa que os autos do inquérito não serão encaminhados ao juiz da instrução e do julgamento, como no sistema italiano de doppio fascicolo (v. ÁVILA, 2016a, p. 41). A regra do art. 3-C, § 3º, do CPP refere-se aos "autos que compõem as matérias de competência do juiz das garantias", e a condução ordinária da investigação criminal não depende de qualquer intervenção do juiz das garantias, apenas as hipóteses de restrições de direitos indicadas no art. 3-B do CPP. Não houve revogação dos artigos 12 e 155 do CPP. Tanto que o juiz da instrução deverá realizar o despacho saneador após a resposta à acusação (CPP, art. 397) e, para tal decisão, precisará necessariamente reavaliar as informações preliminares que sustentam a acusação. Aliás, o fato de o juiz das garantias ser responsável pela decisão de recebimento da denúncia faz recobrar especial valor ao despacho saneador pelo juiz da instrução e do julgamento, pois agora este será o primeiro momento em que este juiz apreciará as condições da ação.

\section{A REGRA DE IMPEDIMENTO ENTRE O JUIZ DAS GARANTIAS E O JUIZ DA INSTRUÇÃO E DO JULGAMENTO}

A grande inovação (e polêmica) quanto ao juiz das garantias é que ele deverá ser um juiz diverso do juiz da instrução e do julgamento, cf. art. 3-D do CPP, havendo uma 
regra de impedimento entre as duas fases. Isso significa que ele poderá ser demandado até o recebimento da denúncia ou a homologação em audiência da celebração do ANPP, que são atos de sua competência (CPP, art. 3-C e art. 28-A, § 4\%). A regra de impedimento para que o juiz que atuou como juiz das garantias não funcione como juiz da instrução e do julgamento (art. 3o-D) é limitada ao efetivo exercício de algum ato decisório. Trata-se de uma nova modalidade de competência funcional pela fase do procedimento, estabelecida com a finalidade de elevar a imparcialidade do juiz da instrução e do julgamento, que agora não poderá ter tido qualquer participação no acompanhamento da investigação criminal.

A regra possui uma lógica. Nas investigações mais complexas, especialmente as relacionadas a organizações criminosas e crimes de colarinho branco, usualmente são necessárias diversas diligências restritivas de direitos fundamentais em sequência. Realiza-se uma interceptação telefônica, que dá a indicação de um novo possível participante da organização, e, por consequência, este é incluído em um novo pedido de outra interceptação telefônica; quebra-se o sigilo bancário, e, com as novas informações de uma nova conta bancária, solicita-se nova quebra de sigilo bancário; quebra-se um sigilo de internet, e, com as novas informações, avança-se sobre uma nova quebra de sigilo; autoriza-se um agente infiltrado e se controla, nas prorrogações, a viabilidade de sucesso no avanço das investigações. Apesar de não ser o juiz quem está realizando a investigação criminal diretamente, mas decidindo sobre pedidos formulados pelo Ministério Público (eventualmente pela autoridade policial), essa atividade do juiz de autorizar em sequência atos de investigação criminal, controlando o avançar do fumus commissi delicti e sua proporcionalidade (especialmente a adequação da diligência, o que exige a análise da probabilidade de sucesso das diligências em cada fase), aproxima muito o juiz da racionalidade investigativa. Em outras palavras, um juiz que seguidamente autorizou a prorrogação de interceptações telefônicas, a quebra de sigilos de diversas contas bancárias, a prisão preventiva de diversos integrantes da organização criminosa terá uma menor capacidade de criticar seu próprio trabalho e reconhecer no julgamento que os indícios eram fracos desde o início contra determinados acusados (v. MATA-MOUROS, 2011).

Segmento doutrinário advoga a existência de um comprometimento psicológico do magistrado que acompanha a investigação criminal, em razão dos diversos prejulgamentos que realiza, gerando uma causa de imparcialidade objetiva, derivada do exercício de uma função no processo (LOPES JUNIOR; RITTER, 2016). Ainda que o magistrado não tenha subjetivamente se sentido como comprometido, a possibilidade do comprometimento gera uma causa objetiva que recomenda o impedimento, elevando a legitimidade do processo penal. Nesse sentido, afirma Silveira (2009, p. 89):

Não tendo o juiz emitido juízo sobre a oportunidade e a conveniência de diligências que invadem direitos fundamentais do investigado, tampouco 
sobre pedidos cautelares, o magistrado entra no processo sem o peso de ter decidido a favor ou contra uma das partes. Não leva consigo o passivo da fase pré-processual. [...] Quer dizer, em nenhum momento compartilhou a perspectiva dos órgãos de persecução penal.

No mesmo sentido, Maya e Lorenzoni (2020, p. 153), analisando a jurisprudência do TEDH, afirmam:

A possibilidade de contaminação subjetiva do juiz, observada de acordo com as peculiaridades de cada caso concreto, gera, no entendimento do TEDH, uma dúvida fundada incompatível com a aparência de imparcialidade que confere legitimidade às decisões do Poder Judiciário.

Portanto, a regra processual cria uma causa de impedimento destinada a elevar a imparcialidade objetiva do juiz da instrução e do julgamento. Por consequência, cria uma divisão funcional de tarefas entre o juiz da investigação e o juiz da instrução e do julgamento. Ainda que se possa argumentar que a inovação gere uma maior especialização pela fase do processo, este não deve ser o argumento central, pois isoladamente não sustentaria uma competência legislativa federal, já que apenas elevar a especialização não é tema processual, mas de organização judiciária estadual (SUXBERGER, 2020). A separação dessas duas fases é uma norma de processo penal e não meramente de procedimentos, pois ela visa a elevar a imparcialidade do magistrado à luz da estrutura acusatória proposta pela Lei n. 13.964/2019 (OLIVEIRA, 2020). O fato de uma norma processual sobre a imparcialidade ter reflexos posteriores na organização judiciária não a torna uma norma procedimental; por exemplo, a Lei n. 9.099/1995 determinou a criação dos Juizados Especiais Criminais, e a Lei n. 11.340/2006 determinou a criação dos Juizados de Violência Doméstica contra a Mulher. Ainda que se trate de uma norma mista, processual e procedimental, como reconhecido na segunda decisão do STF (BRASIL, 2020b), essa circunstância não retiraria a competência da União para editar as normas processuais. Portanto, a opção do legislador federal por acolher uma tendência internacional é constitucionalmente legítima. Ainda que houvesse alguma dúvida sobre o acerto da decisão política, como sustenta Suxberger (2020, p. 93) ser o caso de um "erro legístico", em âmbito de controle de constitucionalidade, "caso os dados empíricos sejam duvidosos, deve prevalecer a decisão do legislador” (MAYA; LORENZONI, 2020, p. 162).

Cumpre analisar se essa regra de garantia, que possui uma justificativa racional, não ofende o princípio da eficiência, igualmente com assento constitucional. Para todas as capitais de Estados e grandes cidades, onde houver mais de um magistrado em exercício, a solução é simples: bastará uma divisão de funções entre os magistrados. Essa reestruturação certamente exigirá um esforço organizativo, mas a reforma é viável. Por exemplo, se houver duas varas criminais, bastará que um juiz seja o juiz das garantias do outro e vice-versa. Em algumas capitais de Estados, já se ensaiou uma experiência 
semelhante, com varas exclusivas para a fase investigativa (as "Centrais de Inquéritos" no Rio de Janeiro ou o Departamento de Inquéritos Policiais - DIPO em São Paulo; v. CARVALHO; MILANEZ, 2020). Portanto, a reforma não está propriamente criando mais trabalho ao Judiciário ou determinando a criação de novos cargos, mas exigindo uma melhor divisão do trabalho, já que um juiz irá perder as atribuições para outro ganhá-las (MAYA; LORENZONI, 2020).

Para as cidades de interior, onde há apenas um magistrado, a questão se complica. Segundo dados do CNJ, em 19\% das comarcas há vara única, as quais são responsáveis por $13 \%$ de todos os procedimentos investigatórios em curso (BRASIL, 2020a, p. 25). A reforma prevê, no art. 3-D, parágrafo único, do CPP, que, nesses casos, deverá ser criado um sistema de rodízio entre magistrados. Parece-nos correto o entendimento do STF de que essa norma invade a competência legislativa estadual e viola a liberdade de auto-organização do Judiciário (BRASIL, 2020a, 2020b), pois será possível tanto a criação de um rodízio quanto de um sistema de substituições recíprocas ou ainda a atribuição a uma vara central, caso o sistema de processo eletrônico o permita. Segundo Oliveira (2020, p. 163), "tal determinação legal extrapola diretrizes gerais, adentra pormenores, buscando esgotar o assunto ou propor solução jurídica uniforme aos entes federados." Parece-nos que essa norma pode trazer entraves concretos à eficiência da investigação criminal nas comarcas de interior, especialmente aquelas de difícil acesso e não integradas ao sistema de processo eletrônico, ao exigir que o juiz de outra comarca venha exercer ordinariamente as funções de juiz das garantias, com substancial gasto público adicional com deslocamentos do juiz ou dos autos a outra cidade para decisão sobre diligências investigativas urgentes, que exigem resposta imediata em regime de plantão (v. ANDRADE, 2020, p. 80).

Uma possível solução seria a implantação do processo judicial eletrônico, com viabilidade de audiências por videoconferência, situação que ganhou fomento durante a pandemia do COVID-19. Todavia, enquanto não se chega a esse estágio de informatização, considerando que essa regra gerará empecilhos concretos à efetividade da persecução penal nas comarcas de vara única, cremos que seria possível o controle de constitucionalidade para uma modulação dos efeitos da reforma nesses contextos muito específicos (cf. Lei n. 9.868/1999, arts. 27 e 28). É possível se aplicar o mesmo entendimento da inconstitucionalidade progressiva já adotado pelo STF, quando reconheceu que o Ministério Público poderia continuar exercendo as funções de Defensoria Pública nos locais em que esta ainda não estivesse estruturada (BRASIL, 1994); todavia, nesse caso, seria uma constitucionalidade progressiva da exigência de separação das funções entre juiz de garantias e o da instrução e do julgamento. Nessa linha, Lopes Junior e Ritter (2016) defendem a possibilidade de regionalização e de concretização progressiva do juiz das garantias. 
Considerando que a maioria dos processos criminais não tramitam nas comarcas de varas única, e sim nas grandes comarcas, onde há vários juízes, a reforma é perfeitamente factível na maioria das situações, tratando-se apenas de uma questão de planejamento (e boa vontade pelo Judiciário). Portanto, afora essa situação excepcional de comarca de vara única de difícil acesso e sem integração com o processo eletrônico, não há inconstitucionalidade na figura do juiz das garantias. Afinal, se Argentina e Chile conseguiram implementar o juiz das garantias até na Patagônia e no deserto do Atacama, o Brasil certamente encontrará as soluções.

Conforme estabelece o novo art. 3-C, caput, do CPP, o juiz das garantias não se aplica ao subsistema das infrações penais de menor potencial ofensivo (Juizado Especial Criminal - JEC). Aqui a lei faz uma ponderação entre garantia e efetividade, pois a necessidade da garantia se torna diminuta, já que, de regra, não há prisão provisória no sistema do JEC, são raros os casos de diligências investigatórias restritivas de direitos fundamentais, e a maioria das soluções dos casos é feita na esfera pré-processual, com a conciliação ou a transação penal. Ademais, as penas são pequenas, o que permite uma flexibilização das garantias. De forma semelhante, no Chile, para casos de menor gravidade (procedimento abreviado, simplificado e monitório), o juiz de garantias pode prosseguir no julgamento (CARVALHO; MILANEZ, 2020).

A primeira decisão liminar do STF na ADIN 6298 (BRASIL, 2020a) proibiu a aplicação do juiz das garantias também para o sistema da Lei Maria da Penha, tribunal do júri, justiça eleitoral e ações penais originárias de tribunais. Essas exceções deveriam ser analisadas sob a perspectiva de necessidade lógica da garantia e de facticidade de sua implementação. Vejamos.

A Lei n. 11.340/2006 prevê, em seu art. 14, que os juizados da mulher terão obrigatoriamente a competência mista cível e criminal. Usualmente essa competência cível está associada às medidas protetivas de urgência. A Lei n. 13.894/2019 acrescentou a competência para julgamento de ações de divórcio e de dissolução da união estável. Entende-se que a efetividade da atuação protetiva do juízo especializado está associada à conjugação dessas competências cíveis e criminais, tendo o STF já julgado que a disposição é constitucional e não ofende a competência legislativa estadual de organização judiciária, pois se trata de norma processual de efetividade da jurisdição (BRASIL, 2012).

A introdução da figura do juiz das garantias no sistema da Violência Doméstica e Familiar Contra a Mulher - VDFCM geraria uma cisão na competência do juiz nas duas fases de investigação e de julgamento criminais. A consequência seria que caberia ao juiz das garantias da VDFCM julgar quanto aos pedidos de Medidas Protetivas de Urgência - MPU ou de divórcio na fase investigativa, deslocando-se a competência cível ao juiz da instrução e julgamento criminal da VDFCM, após o ajuizamento da ação penal, para 
apreciar os eventuais pedidos de concessão ou revogação da MPU e de divórcio. A situação se complicaria caso houvesse sucessão de novos episódios de violência, pois seria possível que o primeiro caso já estivesse em fase de julgamento da ação penal e o novo caso ainda esteja em investigação, com o juiz das garantias. Nesse caso, a competência para apreciação da manutenção ou revogação da MPU e respectivas cautelares criminais quanto ao primeiro fato seria de competência do juiz da instrução e do julgamento e o pedido de MPU e cautelares criminais quanto ao novo fato seria de competência do juiz da investigação. Como há dois crimes, a competência para decretar a prisão preventiva também seria dupla. A questão voltaria a se complicar se, eventualmente, o processo cível tiver uma duração dilatada; suponhamos que o juiz das garantias conceda a MPU e designe audiência de justificação, mas, antes de sua realização, haja o oferecimento e recebimento da denúncia; um ato processual à disposição da parte (oferecimento de denúncia pelo Ministério Público) geraria a perda da competência cível para prosseguir no processamento da MPU, sendo necessário cancelar a audiência e submeter o caso ao juiz da instrução e julgamento. Não raro, nas MPUs, há notícias de descumprimentos que exigem uma audiência de justificação, bem como uma ação de divórcio pode prolongar-se por vários meses, ultrapassando a fase da investigação criminal. Aliás, é mesmo possível haver um pedido de MPU mesmo sem qualquer investigação criminal em curso (ÁVILA, 2019).

O sistema do juiz de garantias acaba trazendo uma diminuição da efetividade do sistema de competência mista unitária da Lei Maria da Penha, já que a comunicação do descumprimento da ordem inicial de MPU sob responsabilidade do juiz da instrução e do julgamento será feita a um juiz diverso, o das garantias, gerando uma competência cível precária e permitindo uma solução de continuidade no andamento do processo cível conexo. Também sujeitará a mulher a uma dualidade de juízes que deveriam ter a mesma função: proteger seus direitos fundamentais com uma visão unitária do ciclo de violência em seus diversos episódios individuais.

Por exemplo, na Espanha, os Juzgados de Violencia contra la Mujer possuem competência tanto para a investigação (instrucción) quanto para o julgamento (conocimiento) das causas de violência contra a mulher, sem a tradicional divisão de funções entre juízes nessas duas fases, exatamente pelo fato de cumularem competência cível (v. art. 17-bis da Ley de Enjuiciamiento Criminal da Espanha, incluído pela Ley Orgánica no $1 / 2004)$.

Portanto, a interpretação sistemática permite a conclusão de que a Lei Maria da Penha possui regra especial de unidade de competência e que a regra geral do juiz de garantias não se aplica a esse subsistema. Apesar desse entendimento pela não aplicação da regra de impedimento do magistrado da investigação para atuar no julgamento, para os casos de VDFCM, a competência de atuação do magistrado na fase investigativa 
deverá se conformar às diretrizes da reforma, nos termos do art. 3-B do CPP, não lhe cabendo iniciativas investigativas.

A primeira decisão liminar do STF na ADIN 6298 (BRASIL, 2020a) entendeu que a necessidade de impedimento do juiz que atua na fase investigativa para atuar no julgamento se torna menos relevante no âmbito do Tribunal do Júri, pois aqui quem realiza o julgamento dos fatos são os jurados e a fase de pronúncia corresponde apenas a uma confirmação em juízo da admissibilidade preliminar da acusação, agora garantida pelo contraditório. Todavia, o entendimento está equivocado, pois a lei cria um requisito objetivo de imparcialidade do magistrado, e a colegialidade não afasta as regras de impedimento ou suspeição. O juiz do júri toma decisões relevantes, como a pronúncia ou a fixação da pena no julgamento plenário, portanto deve submeter-se às regras de imparcialidade objetiva (v. CUNHA, 2020, p. 72). Por exemplo, se o juiz houver funcionado como Delegado de Polícia ou como Promotor de Justiça, não poderá exercer as funções de juiz da instrução e do julgamento da fase de pronúncia ou da instrução e do julgamento plenário do júri. Da mesma forma, o juiz que atuou na fase de julgamento não poderá atuar como Desembargador no julgamento do recurso do mesmo caso, mesmo sendo o caso decidido de forma colegiada (CPP, art. 252 e incisos). A gravidade das penas dos crimes dolosos contra a vida faz recobrar a necessidade de respeito à nova garantia.

A lógica da necessidade do juiz das garantias estaria presente no âmbito da justiça eleitoral. Por outro lado, ordinariamente as zonas eleitorais correspondem a comarcas de vara única, o que exigiria uma logística mais complexa para se chamar magistrado de outra zona para ordinariamente exercer as funções de juiz das garantias (ou de julgamento), com previsível comprometimento da efetividade da atuação jurisdicional. Esse quadro faz recobrar sentido a argumentação de inconstitucionalidade por grave violação ao princípio da eficiência. Todavia, a implementação do processo judicial eletrônico poderá viabilizar a aplicação da garantia.

A decisão da ADIN 6298 entendeu que o juiz das garantias não se aplicaria às ações penais originárias de tribunais, ao argumento de que "a colegialidade, por si só, é fator e reforço da independência e da imparcialidade judicial.” (BRASIL, 2020a, p. 29). Todavia, parece-nos que a diretriz do juiz das garantias também se aplica a esses casos, pois o relator do inquérito é também relator da ação penal, com uma função decisiva no julgamento (v. CARVALHO; MILANEZ, 2020). Enquanto, na violência doméstica e na justiça eleitoral, a implementação do juiz das garantias inviabilizaria gravemente a atividade jurisdicional, aqui parece haver uma solução perfeitamente possível: basta se previr a regra de que o magistrado que funcione como relator na fase investigativa, com as funções de juiz de garantias, estaria impedido de ser o relator e de funcionar na fase de julgamento. Não faz sentido se negar uma garantia quando ela é factível e não 
compromete a efetividade. Essa regra de impedimento para processos originários perante tribunais é utilizada, por exemplo, no art. 288.3 do CPP português.

Há aparente incongruência na lei ao permitir a criação pelos Tribunais de varas criminais colegiadas com "competência para todos os atos jurisdicionais no decorrer da investigação, da ação penal e da execução da pena" em relação a "crimes de pertinência a organizações criminosas armadas ou que tenham armas à disposição", além dos crimes de associação criminosa e conexos respectivos (art. 1-A, caput e $\S 1^{\circ}$, da Lei n. 12.694/2012, incluídos pelo art. 13 da Lei n. 13.964/2019). Pode-se reconhecer uma manifestação do direito penal do inimigo na exceção: para as organizações destinadas à prática de crimes de colarinho branco, possivelmente integradas pelas elites, garantias de imparcialidade ao magistrado; para as organizações criminosas que utilizam armas e milícias, usualmente integradas por segmentos socialmente excluídos, a relativização de garantias (v. GRECO, 2005).

\section{O AFASTAMENTO DO JUIZ DO CONTROLE DO ARQUIVAMENTO DO INQUÉRITO POLICIAL}

O novo art. 28 do CPP retira o juiz da então denominada "função anômala" de fiscal do princípio da obrigatoriedade da ação penal pública, ao apreciar as promoções de arquivamento do inquérito pelo Ministério Público. Essa reforma segue a diretriz do art. 3-A, quanto à estrutura acusatória do processo penal, ao afastar o juiz dessa função de impulsionar a acusação. Agora, quem ordena o arquivamento do inquérito policial é o membro do Ministério Público, o qual submeterá sua decisão à homologação de órgão revisor interno. Trata-se de "verdadeira decisão de não acusar" pelo titular da persecução penal (HIRECHE, 2020, p. 130). Segmento expressivo da doutrina nacional já advogava uma reforma na linha deste controle interno dos arquivamentos enquanto consequência necessária do sistema acusatório (v. ÁVILA, 2016, p. 222; RIBEIRO, 2003, p. 146; LIMA, 2008, p. 160; SILVA, 2010, p. 99-105).

Antes, após a não homologação do arquivamento pelo juiz, o órgão responsável por esse controle interno era o Procurador-Geral de Justiça. A reforma não mais atribuilhe essa função, mas à "instância de revisão ministerial, na forma da lei” (CPP, art. 28, caput). No âmbito do Ministério Público da União, essa instância revisional é exercida pelas Câmaras de Coordenação e Revisão, cf. art. 62, inciso IV, da LC n. 75/1993 (ref. ao Ministério Público Federal). No caso dos Ministérios Públicos estaduais, não há regulamentação na Lei n. 8.625/1993, de sorte que seu art. 80, que remete à aplicação subsidiária da LC n. 75/1993, permite a criação de câmaras de coordenação e revisão para assumir esse novo volume de trabalho. Enquanto não criadas as câmaras, a atribuição continuará a ser exercida pelo Procurador-Geral de Justiça. O órgão revisor 
poderá homologar a promoção de arquivamento, ajuizar a denúncia (ou delegar esta atribuição a outro membro) ou ainda determinar o prosseguimento das investigações.

Trata-se de reforma importante para retirar o juiz da função inquisitorial de indiretamente promover o exercício da ação penal, saindo de sua posição de imparcialidade. Por outro lado, o paradigma do Estado de Direito exige que existam mecanismos de controle sobre o membro do Ministério Público que promove o arquivamento, já que todo poder sem controles tende ao arbítrio. Agora, esse controle, que antes era difuso pelos diversos juízes criminais, passa a ser concentrado em um órgão revisor interno, que poderá dar uniformidade à política criminal de promoção da persecução penal. Agora, o órgão superior do Ministério Público poderá editar diretivas consolidando entendimentos, esclarecendo que determinados fatos devem ser objeto de persecução penal e que outros fatos podem ser objeto de arquivamento em determinadas circunstâncias.

Esse mecanismo fortalece a segurança jurídica e os princípios constitucionais da unidade e indivisibilidade do Ministério Público (CF/1988, art. 127, § 1º). O desafio será construir um sistema que permita que as diretivas do órgão revisor sejam elaboradas de forma democrática, com a participação de todos os membros do Ministério Público (numa construção bottom-up), em diálogo democrático com as demais instituições públicas e a sociedade civil (ÁVILA, 2016a, p. 394). O novo regime permitirá mais uniformidade e transparência democrática à forma como o Ministério Público constrói sua política criminal.

Após essa decisão, deverá haver a comunicação do arquivamento à vítima, ao investigado e à autoridade policial e o encaminhamento dos autos à instância de revisão ministerial para fins de homologação (CPP, art. 28, caput). A vítima poderá ainda, no prazo de 30 dias, juntar razões contrárias ao arquivamento e encaminhá-las ao órgão revisional solicitando a promoção da persecução penal (art. 28, § 1\%), bem como, caso se trate de crime contra a Administração Pública, o referido pedido poderá ser formulado pela chefia do órgão responsável por sua representação judicial (art. 28, § 20). Essa possibilidade de impugnação administrativa pela vítima da decisão ministerial de arquivamento é um importante elemento para elevar a qualidade dos trabalhos nessa fase. Todavia, caso o órgão revisor homologue a decisão de arquivamento, não será possível à vítima impugnar essa decisão perante o Poder Judiciário, pois a decisão de promover a ação penal é exclusiva do Ministério Público (CF/1988, art. 129, inciso I).

Portanto, em regra, nenhuma decisão ministerial de arquivamento do inquérito será submetida à revisão judicial, mesmo em casos de reconhecimento de atipicidade, presença de excludente da ilicitude, de excludente da culpabilidade ou de causa extintiva da punibilidade. Há apenas a decisão do Ministério Público de não acionar o Poder Judiciário, sem necessidade de manifestação judicial. Todavia, permanece vigendo a 
segunda parte do art. 18 do CPP, sendo possível a reabertura das investigações caso surja notícia de possíveis novas provas. Assim, a reforma faz superar a discussão sobre o eventual efeito de coisa julgada quanto à antiga decisão judicial de arquivamento do inquérito policial. Há (e, em verdade, sempre houve) uma decisão administrativa com a cláusula rebus sic stantibus (v. CRUZ, 2008). A decisão de arquivamento do inquérito policial pelo Ministério Público, devidamente homologada pelo órgão revisor interno, é uma decisão administrativa que possui uma condição qualificada para ser revogada: surgimento de novas provas.

Essa regra de não revisão judicial obrigatória não impede, todavia, que o investigado solicite ao juiz das garantias o trancamento das investigações quando houver falta de justa causa, v.g., presença de uma causa extintiva da punibilidade (cf. CPP, art. 3-B, inciso IX). Todavia, não há mais interesse em agir tanto do Ministério Público quanto do investigado em se requerer uma homologação judicial da decisão de não acusação.

É possivel extrair uma possível exceção à regra de que o juiz ordinariamente não homologará arquivamentos: o caso de a lei prever uma audiência judicial na fase préprocessual, durante a qual a causa extintiva da punibilidade seja reconhecida. Essa exceção possuirá especial aplicação no sistema do JEC, pois, se houver composição civil entre as partes ou retratação à representação em audiência, poderá o juiz, diretamente, homologar o acordo e determinar o trancamento das investigações. Solução semelhante deve ser aplicada no sistema da Lei Maria da Penha, para a retratação à representação pela vítima em audiência (Lei n. 11.340/2006, art. 16). Violaria o princípio da eficiência que um ato já submetido ao controle judicial precisasse ser homologado órgão revisor do Ministério Público.

Mesmo nos casos de ação penal privada, não há mais necessidade de uma decisão judicial declarando a extinção da punibilidade pela decadência para o arquivamento do inquérito. Haverá, tão somente, o não exercício da ação penal pelo querelante. Como não há mais competência judicial para o processamento de inquérito policial, perdeu o sentido a regra do art. 19 do CPP, relativo à remessa dos autos ao juiz, em caso de ação penal privada, para se aguardar a iniciativa da parte. Nessas situações, caso o Ministério Público, enquanto gestor da fase investigativa, declare que não consta dos autos do inquérito notícia de crime de ação penal pública (a ser eventualmente arquivada), deverá notificar a vítima do esclarecimento da autoria e informar-lhe que os autos estão à sua disposição pelo prazo decadencial. Por exemplo, em Portugal, a renúncia ao direito de queixa, realizada na fase das investigações, é homologada diretamente pelo Ministério Público (CPP português, art. 51.2).

Caso haja medidas cautelares em curso (como a fiança), o arquivamento do inquérito gerará a perda de justa causa para a continuidade da medida cautelar. $\mathrm{O}$ ideal 
seria, de lege ferenda, que o Ministério Público pudesse determinar diretamente a devolução dos valores depositados, comunicando o juiz das garantias da perda de justa causa para a medida cautelar, com posterior baixa no procedimento judicial que acompanhava essa medida cautelar. Em outras palavras, para haver restrição de direitos fundamentais em um sistema acusatório, é necessário o concurso de duas autoridades, Ministério Público (demanda) e juiz das garantias (decisão), mas, para cessar a restrição, basta que uma das autoridades não mais a autorize. Vale lembrar que a fiança não está sujeita à reserva de jurisdição, já que a própria autoridade policial pode fixá-la para crimes com pena privativa de liberdade não superior a 4 anos (CPP, art. 322, caput). Caso o Ministério Público entenda que houve quebramento da fiança, poderá demandar ao juiz das garantias para aplicar a sanção respectiva (CPP, art., 341 a 346). Da mesma forma, se houver necessidade de decretação de perdimento de bens ilícitos (v.g., armas apreendidas, cf. Lei n. 10.826/2003, art. 25), na atual sistemática, será necessária ordem judicial de destruição.

A reforma traz um incremento substancial de trabalho ao Ministério Público, com rotinas cartorárias de intimação das partes e mais trabalho às Câmaras de Coordenação e Revisão. Por outro lado, a reforma também traz uma diminuição de trabalho aos órgãos ministeriais, com a criação do ANPP, que evitará o ajuizamento de diversas ações penais para crimes de médio potencial ofensivo. Portanto, não padece de inconstitucionalidade uma reforma que traz ao mesmo tempo uma elevação e uma diminuição de atribuições ministeriais. Sobre esses desdobramentos da nova atribuição ministerial para arquivamento do inquérito, vislumbra-se a conveniência de haver, em breve, nova reforma para melhor regulamentação, mas a interpretação sistemática já permite construir soluções imediatas às eventuais lacunas.

\section{A FUNÇÃO JUDICIAL DE CONTROLE DO ACORDO DE NÃO PERSECUÇÃO PENAL}

O último ponto relevante da reforma é a legalização do ANPP, anteriormente criado pelo CNMP por meio da Resolução no 181/2017, art. 18 (posteriormente alterada pela Resolução n. 183/2018). A inovação do CNMP criou ávido debate (v. CUNHA et al., 2017), com discussões principais na perspectiva político-criminal e jurídica. A primeira discutia a conveniência do instituto e a outra, a legitimidade de sua criação via mera resolução do CNMP e não por meio de lei. Com a reforma, o legislador faz sua opção político-criminal, e supera-se a discussão quanto à eventual ilegalidade da resolução.

Há muito tempo, critica-se o princípio da obrigatoriedade da ação penal, entendendo-se que os "espaços de consenso" são essenciais à solução do caso criminal 
(CUNHA et al., 2017). Ainda que segmento doutrinário advogue que a perspectiva acusatória, marcada pelo julgamento contraditório, seria incompatível com a justiça negocial (FERRAJOLI, 2002, p. 456; PRADO, 2005). O alargamento da solução negocial é uma das tendências de um modelo acusatório no contexto Latino-Americano (GRINOVER, 2000).

Um esboço desse modelo de justiça negocial não conflitiva com mediação judicial foi introduzido no Brasil pela Lei n. 9.099/1995, que criou para as infrações penais de menor potencial ofensivo (pena máxima de até dois anos) os institutos da conciliação civil e transação penal no âmbito do microssistema do JEC, além de criar a suspensão condicional do processo para crimes de médio potencial ofensivo (pena mínima até um ano) para as varas criminais. A colaboração premiada é igualmente outro exemplo dessa tendência negocial, estando prevista em diversas leis, tendo sua versão mais abrangente regulamentada na Lei das Organizações Criminosas (Lei n. 12.850/2013, arts. 4º a 7o).

A justiça negocial é um fenômeno de funcionalização do sistema processual, reconhecida como uma tendência internacional de utilização de institutos que tiveram uma inspiração inicial no plea bargaining, ainda que tenham desenvolvido distinções específicas de cabimento e liberdade negocial quanto ao conteúdo (v. SUXBERGER; GOMES FILHO, 2016). Apesar da tendência, problemas também são apontados, como a prática de overcharging, consistente em o Ministério Público formular acusações excessivas para obter condições mais gravosas no acordo, a celebração de acordos para casos fadados ao arquivamento, com a "indução processual" do acusado a celebrar acordos gravosos pelo risco da acusação prosseguir (v. SCHÜNEMANN, 2013, p. 240). Podemos acrescentar ainda o problema da banalização da responsabilização por esse acordo, com cláusulas vazias (como o mero comparecimento periódico em juízo), o que levou v.g. a um movimento de resistência à sua utilização no âmbito da VDFCM.

Para os propósitos desse trabalho, cumpre destacar que o juiz é afastado da função de protagonista na negociação das cláusulas do acordo, nem poderá modificar as cláusulas sem concordância das partes, competindo-lhe tão somente controlar a sua legalidade.

O ponto central da estrutura acusatória no ANPP é que a atribuição para elaborar a proposta com as condições do acordo cabe ao Ministério Público, se presentes algumas condições autorizativas ou positivas (CPP, art. 28-A, caput) e ausentes as condições proibitivas ou negativas (CPP, art. 28-A, § 2). Na sistemática da lei, o ANPP é celebrado de forma extrajudicial e antes do ajuizamento da denúncia, entre Ministério Público e o investigado e seu defensor, sendo suas cláusulas reduzidas a termo e submetidas à homologação judicial, em regra, pelo juiz das garantias. O juiz deverá realizar uma análise preliminar quanto à adequação do acordo, ou seja, poderá devolver os autos ao Ministério Público para ajustar a proposta caso considere "inadequadas, 
insuficientes ou abusivas as condições" (CPP, art. 28-A, § 50) ou ainda recusar a homologação se não estiverem presentes os requisitos acima indicados. Verificada a admissibilidade do acordo, o juiz das garantias designará audiência para ratificar a livre manifestação de vontade do investigado e seu defensor. Uma vez ratificado o acordo, a vítima deverá ser intimada $\left(\S 9^{\circ}\right)$ e sua fiscalização será feita perante o juiz da execução (§ 6o).

Dentro da lógica acusatória, se o membro do Ministério Público recusar a proposta de acordo, não cabe ao magistrado aplicar a regra do art. 28 para que o órgão revisor do Ministério Público apresente proposta, tão somente o investigado tem essa legitimidade (CPP, art. 28-A, § 14). Não pode o juiz participar das negociações para a celebração do ANPP nem alterar as condições da proposta sem concordância de ambas as partes, cabendo-lhe propor ao Ministério Público a reformulação do acordo (CPP, art. 28-A, $\S 5^{\circ}$ ) ou, em caso de recusa de alteração, deixar de homologá-lo $\left(\S 7^{\circ}\right)$, abrindo-se a via da continuidade da persecução penal. Contra a recusa judicial de homologação do ANPP, o investigado ou o Ministério Público poderão interpor recurso em sentido estrito (CPP, art. 581, inciso XXV). Apesar de a lei não proibir, parece ser possível que haja a celebração do acordo pelo Ministério Público em sede jurisdicional, em semelhança à suspensão condicional do processo, situação em que o juiz deverá se conformar ao seu papel de órgão de controle e não de negociador principal, não sendo possível a realização de ato de investigação (como a colheita da confissão) perante o magistrado.

\section{ANÁLISE CRÍTICA DA CONVERGÊNCIA DA REFORMA A UM MODELO ACUSATÓRIO PROJETADO À INVESTIGAÇÃO CRIMINAL}

As três inovações legislativas analisadas representam a convergência rumo à introdução de princípios ligados ao sistema acusatório na fase da investigação criminal, pois asseguram um afastamento do juiz das funções típicas de promoção da persecução penal. A principal dessas inovações está ligada ao instituto do juiz das garantias, que claramente afasta o magistrado da iniciativa de atos investigativos ou de determinação de medidas cautelares ex officio, reservando-o a uma posição de maior imparcialidade para as decisões relacionadas aos requerimentos de restrição de direitos fundamentais ao investigado ou ainda à impugnação pelo investigado de eventuais ilegalidades. Assim, o juiz deixa de ser um fiscal da eficiência da investigação criminal. A regra de impedimento entre o juiz das garantias e o juiz da instrução e do julgamento igualmente fortalece a imparcialidade objetiva do magistrado, fomentando uma "originalidade cognitiva” (CARVALHO; MILANEZ, 2020, p. 106). A implantação do juiz das garantias 
foi essencial em diversos países para fomentar uma mudança de cultura jurídica, rumo a um sistema processual mais democrático (MAYA; LORENZONI, 2020).

Segundo Hireche (2020, p. 126), o antigo controle do arquivamento pelo juiz é "uma antiga característica inquisitória do sistema processual penal brasileiro". Por esse motivo, o afastamento do juiz do controle do arquivamento do inquérito representa, igualmente, um corolário da separação de funções, pois permitir-lhe discordar da promoção de arquivamento é um equivalente indireto à promoção da acusação.

Finalmente, a retirada do magistrado das negociações do ANPP, reservando-lhe uma posição de controle da admissibilidade do acordo e da legalidade das condições, igualmente fortalece essa sua posição de não responsabilidade pelo sucesso das investigações e do resultado da persecução na fase preliminar. Apesar de institutos de justiça negociada serem típicos de experiências estrangeiras de sistemas acusatórios, elas exigem igualmente um efetivo abandono dos ranços inquisitivos na cultura jurídicocriminal. Nesse sentido, David (2020, p. 18) afirma que: "a estruturação da justiça negociada só é possível em um modelo no qual o juiz passa a ser expectador do processo para materializar e preservar as garantias do réu. Logo, para ser válida e legítima, a roupagem justiça negocia exige um corpo acusatório ou adversarial.” Igualmente, a legitimidade do ANPP exigirá um fortalecimento da Defensoria Pública, enquanto órgão de defesa da maioria dos sujeitos passivos da persecução penal em um país de desigualdades abissais. Considerando que a premissa do ANPP é não ser caso de arquivamento, a moldura acusatória deve permitir ao investigado instrumentos para influenciar o acusador a formar adequadamente sua opinio delicti, evitando pretensões acusatórias infundadas ou excessivas. $\mathrm{O}$ recurso para o órgão revisor interno (CPP, art. 28-A, § 14) parece ser a solução para impugnar uma "proposta excessiva" como recusa de proposta adequada.

É possível reconhecer um fortalecimento da atuação do Ministério Público enquanto gestor da fase investigativa, controlando diretamente as prorrogações de prazo para continuidade das investigações, em se tratando de investigado solto, arquivando internamente as investigações criminais e tendo liberdade para entabular, de forma extrajudicial, o acordo de não persecução criminal, com posterior homologação judicial. Igualmente, a reforma acentua sua responsabilidade exclusiva em zelar pela qualidade da atividade investigativa e, portanto, pelo eventual sucesso da persecução penal. Essa atribuição acusatória exclusiva do Ministério Público é uma "garantia da garantia da imparcialidade, fundamental para assegurar a isenção anímica do juiz" (MAYA; LORENZONI, 2020, p. 95).

A Lei n. 13.964/2019 maximiza o direito de defesa, ao regulamentar a audiência de custódia e os instrumentos de impugnação de ilegalidades perante o juiz das garantias, como o trancamento de inquérito sem justa causa ou o direito de vista dos 
autos à defesa. Os direitos de ciência e participação pela defesa também são fortalecidos, com a regra de intimação do investigado após a promoção de arquivamento pelo Ministério Público. Os direitos da vítima são igualmente contemplados na reforma, ao se prever que seja intimada da decisão de arquivamento e que possa encaminhar razões ao órgão revisor do Ministério Público para eventualmente reformar a decisão de arquivamento, bem como na sua intimação quando houver homologação do acordo de não persecução penal e de seu descumprimento.

\section{CONSIDERAÇÕES FINAIS}

A nova estrutura acusatória da investigação criminal fortalece todos os atores processuais dentro de um procedimento mais legítimo e democrático. Não se trata de norma procedimental, mas de verdadeiras normas de processo, que visam a elevar a imparcialidade do magistrado. A opção legislativa alinha-se com uma tendência internacional de afastar o juiz da condução de investigações criminais e de funções associadas à fiscalização do sucesso da persecução penal. $\mathrm{O}$ afastamento do controle do arquivamento do inquérito e da iniciativa de celebração do ANPP alinha-se a essa racionalidade acusatória. A reforma traz o potencial de fomentar uma nova cultura jurídica menos autoritária mais alinhada com valores de respeito aos direitos fundamentais.

Trata-se de opção política compatível com o quadro constitucional, não cabendo ao Supremo Tribunal Federal se imiscuir de forma aprofundada no mérito desta opção. Eventuais questões procedimentais em aberto com a reforma devem ser solucionadas com o recurso à interpretação sistemática.

Todavia, a regra de impedimento do juiz das garantias merece algum temperamento nas situações de grave comprometimento da efetividade do sistema de justiça, como na situação excepcional das comarcas de juiz único, de difícil acesso, ainda sem processo judicial eletrônico, em que se inviabilize a pronta tutela jurisdicional em situações de urgência, bem como nos casos de violência doméstica contra a mulher, diante da necessária competência mista cível e criminal e da visão unitária do ciclo da violência. Aqui seria possível aplicar o entendimento de uma "inconstitucionalidade progressiva”.

Usualmente integrantes do sistema jurídico possuem tendência de serem críticos a reformas, já que elas os retiram de uma situação de acomodação e exigem novos arranjos. Newton chamaria isso de tendência de inércia do movimento. Todavia, a criação do juiz das garantias representa um inegável avanço civilizacional no processo penal brasileiro, concretizando a estrutura acusatória na fase investigativa, elevando a imparcialidade judicial e permitindo melhor clareamento das funções dos sujeitos 
processuais e das garantias de um processo justo. Que mudemos nossas mentalidades e venham os novos tempos de um processo penal mais democrático.

\section{REFERÊNCIAS}

ANDRADE, Mauro Fonseca. Juiz das garantias. 3. ed. Curitiba: Juruá, 2020.

ANDRADE, Mauro Fonseca. Sistemas processuais penais e seus princípios reitores. Curitiba: Juruá, 2008.

ARGENTINA. Ley 27.063. Sancionada: Diciembre 4 de 2014. Disponível em: https:// www.acnur.org/fileadmin/Documentos/BDL/2017/10947.pdf. Acesso em: 3 jun. 2020.

ÁVILA, Thiago Pierobom de. Investigação criminal: o controle externo de direção mediata pelo Ministério Público. Curitiba: Juruá, 2016a.

ÁVILA, Thiago Pierobom de. Audiência de custódia: avanços e desafios. Revista de Informação Legislativa, n. 211, p. 301-333, $2016 b$.

ÁVILA, Thiago Pierobom de. Medidas protetivas da Lei Maria da Penha: natureza jurídica e parâmetros decisórios. Revista Brasileira de Ciências Criminais, v. 27, n. 157, p. 131-174, 2019.

BADARÓ, Gustavo Henrique Righi Ivahy. Direito ao julgamento por juiz imparcial: como assegurar a imparcialidade objetiva do juiz nos sistemas em que não há a função do juiz das garantias. In: BONATO, Gilson (org.). Processo penal, Constituição e crítica: estudos em homenagem ao Prof. Dr. Jacinto Nelson de Miranda Coutinho. Rio de Janeiro: Lumen Juris, 2011. p. 343-363.

BRASIL. Supremo Tribunal Federal. ADIN 4424. Rel. Min. Marco Aurélio, Pleno, j. 9 fev. 2012.

BRASIL. Supremo Tribunal Federal. ADIN 5240. Rel. Min. Luiz Fux, j. 20 ago. 2015, DJe, 1 fev. 2016.

BRASIL. Supremo Tribunal Federal. ADI 6298. Relator Min. Luiz Fux. Decisão monocrática Min. Dias Toffoli. 2020a. Disponível em: http://portal.stf.jus.br/processos/detalhe.asp?incidente=5840274. Acesso em: 3 jun. 2020 .

BRASIL. Supremo Tribunal Federal. ADIN 6299. Relator Min. Luiz Fux, decisão monocrática. 2020b.

Disponível

em: 
http://portal.stf.jus.br/processos/detalhe.asp?incidente $=5840373$. Acesso em: 3 jun. 2020.

BRASIL. Supremo Tribunal Federal. HC 92.893/ES. Rel. Min Ricardo Lewandowski, Pleno, j. 2 out. 2008. Disponível em: https://www.jusbrasil.com.br/busca?q=HC+92893. Acesso em: 3 jun. 2020.

BRASIL. Supremo Tribunal Federal. RE 135328/SP. Rel. p/ ac. Min. Sepúlveda Pertence, Pleno, j. 29 jun. 1994.

CARVALHO, Luis Gustavo Grandinetti Castanho de; MILANEZ, Bruno Augusto Vigo. O juiz de garantias no Brasil e no Chile: breve olhar comparativo. Revista Brasileira de Ciências Criminais, v. 28, n. 168, p. 93-123, 2020.

CEPEDA, Bartolo Pablo Rodríguez. Metodologia jurídica. 7. ed. San Rafael, México: Oxford Press, 2006.

CHILE. Ley n. 19.696, 29 septiembre 2000. Establece Codigo Procesal Penal. Disponível em: https://www.bcn.cl/leychile/navegar?idNorma=176595. Acesso em: 3 jun. 2020.

CHOUKR, Fauzi Hassan. O juiz das garantias na reforma do Código de Processo Penal. In: BONATO, Gilson (org.). Processo penal, Constituição e crítica: estudos em homenagem ao Prof. Dr. Jacinto Nelson de Miranda Coutinho. Rio de Janeiro: Lumen Juris, 2011. p. 267-276.

CRUZ, Rogerio Schietti Machado. A proibição de dupla persecução penal. Rio de Janeiro: Lumen Juris, 2008.

CUNHA, Rogério Sanches et al. (org.). Acordo de não persecução penal: resolução 181/2017 do CNMP. Salvador: Juspodivm, 2017.

CUNHA, Rogério Sanches. Pacote Anticrime: lei n. 13.964/2019. Salvador: JusPodvm, 2020.

DAVID, Décio Franco. O futuro exige o novo: o acordo de não persecução penal exige a implementação de um sistema acusatório. In: BEM, Leonardo Schimitt de; MARTINELLI, João Paulo (org.). Acordo de não persecução penal. Belo Horizonte: D’Plácido, 2020. p. 13-25.

FERNÁNDEZ, Roberto Santacruz; MORALES, David Santacruz. El nuevo rol de la víctima en el sistema penal acusatorio en México. Revista de Derecho UCUDAL, n. 17, p. 85-112, 2018. 
FERRAJOLI, Luigi. Direito e razão: teoria do garantismo penal. Tradução Ana Paula Zomer et al. São Paulo: RT, 2002.

GIACOMOLLI, Nereu José. Juiz de garantias: um nascituro estigmatizado. In: MALAN, Diogo; MIRZA, Flávio (org.). Setenta anos do código de processo penal brasileiro: balanço e perspectivas de reforma. Rio de Janeiro: Lumen Juris, 2011. p. 299-308.

GRECO, Luís. Sobre o chamado direito penal do inimigo. Revista da Faculdade de Direito de Campos, v. 6, n. 7, p. 211-247, 2005.

GRINOVER, Ada Pellegrini. O código modelo de processo penal para Ibero-América 10 anos depois. Derecho PUCP, v. 53, p. 949-959, 2000.

HIRECHE, Gamil Föppel El. Do inquisitório ao acusatório(?): a nova redação do artigo 28 do CPP. Revista de Direito Penal, Processo Penal e Constituição, v. 6, n. 1, p. 118 $135,2020$.

LIMA, Marcellus Polastri. Curso de processo penal. 3. ed. Rio de Janeiro: Lumen Juris, 2008. v. 1.

LOPES JUNIOR, Aury. Sistemas de investigação preliminar no processo penal. 2. ed. Rio de Janeiro: Lumen Juris, 2003.

LOPES JUNIOR, Aury; RITTER, Ruiz. A imprescindibilidade do juiz das garantias para uma jurisdição penal imparcial: reflexões a partir da teoria da dissonância cognitiva. Revista Duc In Altum Cadernos de Direito, v. 8, n. 16, p. 55-91, set./dez. 2016.

MARQUES, José Frederico. Estudos de direito processual. Rio de Janeiro: Forense, 2019.

MATA-MOUROS, Maria de Fátima. Juiz das liberdades: a desconstrução de um mito do processo penal. Coimbra: Almedina, 2011.

MAYA, André Machado. O juizado de garantias como fator determinante à estruturação democrática da jurisdição criminal: o contributo das reformas processuais penais latinoamericanas à reforma processual penal brasileira. Revista Novos Estudos Jurídicos, v. 23, n. 1, p. 71-88, 2018.

MAYA, André Machado; LORENZONI, Pietro Cardia. Sobre a constitucionalidade do juiz de garantias: uma análise das medidas liminares deferidas nas ADIs 6.298, 6.299, 6.300 e 6.305 a partir da teoria dos espaços dogmáticos de Robert Alexy. Revista Brasileira de Ciências Criminais, v. 28, n. 174, p. 151-176, 2020. 
MESQUITA, Paulo Dá. Direcção do inquérito penal e garantia judiciária. Coimbra: Coimbra Ed., 2003.

OLIVEIRA, Felipe Braga de. Juiz das garantias: o nascimento legislativo do juiz das investigações e sua constitucionalidade formal. Revista de Direito Penal, Processo Penal e Constituição, v. 6, n. 1, p. 157-174, 2020.

PRADO, Geraldo. Sistema acusatório. 3. ed. Rio de Janeiro: Lumen Juris, 2005.

RIBEIRO, Diaulas Costa. Ministério Público: dimensão constitucional e repercussão no processo penal. São Paulo: Saraiva, 2003.

SANTIN, Valter Foleto. O Ministério Público na investigação criminal. 2. ed. Bauru: EDIPRO, 2007.

SCHNEIDER, Gabriela; CALLEGARI, André Luís. A relação histórica entre o processo de aquisição de direitos e o sistema acusatório no Brasil. Revista Brasileira de Ciências Criminais, v. 149, p. 195-226, 2018.

SCHÜNEMANN, Bernd. Um olhar crítico ao modelo processual penal norteamericano. In: GRECO, Luís (org.). Estudos de direito penal, direito processual penal e filosofia do direito. São Paulo: Marcial Pons, 2013. p. 241-261.

SILVA, Edimar Carmo da. O princípio acusatório e o devido processo legal. Porto Alegre: Núria Fabris, 2010.

SILVEIRA, Fabiano Augusto Martins. O Código, as cautelares e o juiz das garantias. Revista de Informação Legislativa, v. 46, n. 183, p. 77-93, 2009.

SUXBERGER, Antonio Henrique Graciano. O juiz das garantias como caso de erro legístico. Revista de Informação Legislativa, v. 57, n. 228, p. 93-114, 2020.

SUXBERGER, Antonio Henrique Graciano; GOMES FILHO, Dermeval Farias. Funcionalização e expansão do Direito Penal: o Direito Penal negocial. Revista de Direito Internacional, Brasília, v. 13, n. 1, p. 377-396, 2016.

TEDH. Piersack v. Belgium, Application no 8692/1979, j. 1 out. 1982.

\section{Como citar este documento:}

ÁVILA, Thiago Pierobom de. A estrutura acusatória da investigação criminal: análise a partir da Lei n. 13.964/2019. Revista Opinião Jurídica, Fortaleza, v. 19, n. 32, p. 1-31, set./dez. 2021. 